\title{
DESCRIPTION OF HETEROBASIDION ANNOSUM POPULATION OCCURRING IN SCOTS PINE STANDS IN CZLOPA FOREST DISTRICTS II. MYCELIUM DEVELOPMENT IN A DEAD WOOD
}

\author{
Radosław Cieślak ${ }^{1}$, Jolanta Behnke-Borowczyk ${ }^{2}$, Tomasz Raźny ${ }^{2}$, \\ Marta Molińska-Glura ${ }^{3}$, Anna Ratajczak ${ }^{2}$, Arleta Świetlik ${ }^{2}$, \\ Piotr Łakomy ${ }^{2}$ \\ ${ }^{1}$ The State Forests National Forest Holding \\ ${ }^{2}$ Poznań University of Life Sciences \\ ${ }^{3}$ PUMS - Poznan University of Medical Sciences
}

\begin{abstract}
The aim of this study was to test the ability of dead wood colonization of Heterobasidion annosum isolates with known aggressiveness to the Scots pine seedlings. The experiment was established in Scots pine stand localized in the Człopa Forest District. Roots of six-month-old stumps were inoculated with mycelium of 19 genotypes of H. annosum Genotypes colonized wood of Scots pine roots on distance from $8.10 \mathrm{~cm}$ to $43.27 \mathrm{~cm}$. The genotypes that colonized wood on a shortest distance and the most extensively differed significantly from others. The analysis of the ability of wood colonization by mycelium of genotypes in relations to its origin showed that genotypes collected from stumps overgrew the roots slightly stronger (about 14.5\%) than those collected from trees, but differences were not significant. There were no differences between genotypes isolated from pines and beaches, either. Population of $H$. annosum differed in genotypes features conditioning the rate of its development in the environment and disease dynamics. Differentiation of these features of pathogen populations caused an unequal infection and disease development rate in stands. It seems that the most aggressive isolates colonize the stand fastest through root system.
\end{abstract}

Key words: Heterobasidion annosum, genets, Scots pine, saprotrophic growth

Corresponding author - Adres do korespondencji: Prof. dr hab. Piotr Łakomy, Department of Forest Pathology, Poznań University of Life Sciences, Wojska Polskiego 71 C, 60-625 Poznań, Poland, e-mail: plakomy@up.poznan.pl

(C) Copyright by Wydawnictwo Uniwersytetu Przyrodniczego w Poznaniu, Poznań 2015 


\section{INTRODUCTION}

Heterobasision spp. are the most important pathogens in coniferous stands in boreal climate zone. They play a particular role in stands growing both in the first and second generation on the post-arable soil. Stands are infested by basidiospores, which infect the stumps surfaces or get into the soil with rain and colonize via the root wounds. In addition basidiospores infected wounds in root collar of Norway spruce. The secondary spread of pathogen is caused by mycelium transfer through root system connections from stumps to neighbour stumps or trees (Korhonen et al., 1998; Redfern and Stenlid, 1998; Stenlid and Redfern, 1998; Mańka, 2005).

Stumps and roots are the most important source of the pathogens in infested stand. After primary infection by basidiospores in stands only small genotypes are present that occupied one stump, but after several years of disease development the mycelium is transferred via root contacts. In the second generation of stand on the post arable soil the mycelium of single genotypes spread for longer distance and cover even more than $200 \mathrm{~m}^{2}$ of forest area (Dalke and Łakomy, 2009; Cieślak et al., 2011).

The share of root and butt rot diseases of the whole area of all diseases appearing in Polish forests reached $76.7 \%$ in 2013 . Moreover, the pathogens cause severe damages in stands on the area of 220 thousands hectares, i.e. $2.89 \%$ of the whole area of State Forests in Poland.

A lot of geneotypes occurred in the stands influenced by a high diversity in pathogen's population, consisting of many organisms, which differ between each other of virulence, speed of wood colonization, and the ability of competitions with other microorganisms coexisting in the same ecological niche (Łakomy et al., 2007; Dalke and Łakomy, 2009).

The aim of this study was to test the ability of dead wood colonization of Heterobasidion annosum isolates with known aggressiveness (Cieślak et al., 2011) to the Scots pine seedlings.

\section{MATERIAL AND METHODS}

\section{Pathogen}

Nineteen isolates represented different genotypes of $H$. annosum have been used in these experiments. Pathogens were isolated from Scots pine stumps and dead trees localized in three stands - two 45-year-old (A, C) and from 12-year-old (B) pines and beeches planted in gaps of 33-year-old stand. All stands were localized in the Człopa Forest District and growing on the post-agricultural soil (pedzol). Identification of the pathogen's species was made with the aid of mating tests (Korhonen, 1978), and genets diversity on the base of somatic compatibility (Stenlid, 1985). Genetic relationships of population were described using DNA extraction in previous work (Cieślak et al., 2011). The inoculum consisted of $5 \mathrm{~cm}$ long and $1 \mathrm{~cm}$ in diameter wooden sticks overgrown by $H$. annosum mycelium. 


\section{The rate of growth in Scots pine stumps}

The experiment was established in division 279d localized in the Człopa Forest District, Jaglice Range. The six-months-old stumps leaving after last thinning were chosen and the main roots of them were cleaned from the soil. In each root a hole of $1 \mathrm{~cm}$ in diameter was made by a drill $50 \mathrm{~cm}$ far from the stump. Inoculum of pathogen was put in each hole and next the place was covered by artificial cork (Lac Balsam ${ }^{\circledR}$, Germany) and a root by soil. The control roots were inoculated with sterile wooden sticks. Three main roots of single stumps were inoculated with one pathogen genotype. Twelve months after inoculation the roots were collected and transferred to the laboratory. Root were cut $50 \mathrm{~cm}$ away from the inoculation point the both sides (towards and from stumps). In the laboratory all rots were tap water washed and dried with sterile filter paper. After that roots were split along fibers. The lengths of discoloration zone were measured in two directions. In addition the isolation of mycelium was made from each root. Inoculums were put on 1\% malt extract agar (Merck, Germany) in Petri dishes and after 4-5 days were investigated on the presence of Siiniger meinekellus (A.J. Olson) Stalpers conidial stage of Heterobasidion annosum (Stenlid and Swedjemark, 1988; Werner and Lakomy, 2002).

The multifactorial analysis of variance was used (ANOVA/MANOVA) and HSD Tuckey's test. The Statistica v. 6 (2003) (Bobrowski, 1980; Kala, 2002) was used to verify the basic hypothesis.

\section{RESULTS}

The length of discoloration zone caused in stumps roots by $H$. annosum genotypes was shown in Table 1. The most extensive genotype BCZ3 in colonization spread in dead wood of stump roots on average distance $43.27 \mathrm{~cm}$ and the less intensively growth of mycelium displayed genotypes BCZ1 $(8.10 \mathrm{~cm})$. Other genotypes colonized wood of Scots pine roots on distance from $18.40 \mathrm{~cm}$ (BCZ4) to $40.47 \mathrm{~cm}$ (ACZ1). The mycelium of genotypes collected from plot A overgrew the wood (average $30.17 \mathrm{~cm}$ ) $17 \%$ more expansively than mycelium of genotypes from plot B (average $25.32 \mathrm{~cm}$ ) and $3 \%$ from plot C (average $29.44 \mathrm{~cm}$ ). The mycelium of genotypes originated from plot A spread in roots' wood on distance from $19.60 \mathrm{~cm}$ (ACZ2) to $40.47 \mathrm{~cm}$ (ACZ1), from plot B on distance $8.20 \mathrm{~cm}(\mathrm{BCZ1})$ to $43.27 \mathrm{~cm}(\mathrm{BCZ3})$ and from plot $\mathrm{C}$ on distance from 20.03 $\mathrm{cm}(\mathrm{CCZ10})$ to $35.17 \mathrm{~cm}$ (CCZ11) (Table 1). The only genotype BCZ1 colonized wood on a distance shorter than $10 \mathrm{~cm}$. Six genotypes $(31 \%)$ overgrew the wood on distance from $20 \mathrm{~cm}$ to $30 \mathrm{~cm}$, seven genotypes $(37 \%)$ on distance from $30 \mathrm{~cm}$ to $40 \mathrm{~cm}$ and two genets colonized wood on distance longer than $40 \mathrm{~cm}$.

The differences among genotypes in ability of wood colonization were significant $(p<0.05$; Table 2). The genotypes that colonized wood on the shortest distance differed significantly $(p<0.05)$ from others. And in the opposite site those genotypes which overgrew roots wood on distance more than $30 \mathrm{~cm}$ differed significantly $(p<0.05)$ from 
Table 1. Length of wood discoloration in stumps roots inoculated by $H$. annosum genotypes, twelve months after inoculation

Tabela 1. Długość przebarwienia drewna korzeni pniakowych inokulowanych przez genotypy H. annosum dwanaście miesięcy po zakażeniu

\begin{tabular}{|c|c|c|c|}
\hline \multirow{2}{*}{$\begin{array}{l}\text { Genotype code } \\
\text { Kod genotypu }\end{array}$} & \multicolumn{3}{|c|}{ Discoloration length, $\mathrm{cm}$ - Długość przebarwienia, $\mathrm{cm}$} \\
\hline & $\max$ & $\min$ & $\begin{array}{l}\text { average } \\
\text { średnia }\end{array}$ \\
\hline ACZ1 & 41.20 & 40.00 & 40.47 \\
\hline ACZ2 & 22.70 & 16.80 & 19.60 \\
\hline $\mathrm{ACZ3}$ & 31.50 & 29.30 & 30.47 \\
\hline $\mathrm{BCZ1}$ & 9.60 & 5.20 & 8.10 \\
\hline $\mathrm{BCZ} 2$ & 20.6 & 19.00 & 20.00 \\
\hline BCZ3 & 43.50 & 43.00 & 43.27 \\
\hline BCZ4 & 19.50 & 16.90 & 18.40 \\
\hline BCZ5 & 26.40 & 24.50 & 25.50 \\
\hline BCZ6 & 38.10 & 36.20 & 36.63 \\
\hline $\mathrm{CCZ1}$ & 35.80 & 31.10 & 33.63 \\
\hline CCZ2 & 32.20 & 30.90 & 31.33 \\
\hline CCZ4 & 30.70 & 18.70 & 25.60 \\
\hline CCZ5 & 28.00 & 25.00 & 26.63 \\
\hline CCZ6 & 31.00 & 28.70 & 29.50 \\
\hline CCZ7 & 31.20 & 28.00 & 29.17 \\
\hline CCZ8 & 35.00 & 27.80 & 32.17 \\
\hline CCZ9 & 36.10 & 22.80 & 31.20 \\
\hline CCZ10 & 25.80 & 13.00 & 20.03 \\
\hline CCZ11 & 38.30 & 31.80 & 35.17 \\
\hline $\begin{array}{l}\text { Control } \\
\text { Kontrola }\end{array}$ & 4.45 & 0.05 & 2.17 \\
\hline
\end{tabular}

others. The analyze of the ability of wood colonization by mycelium of genotypes in relations to its origin showed that genotypes collected from stumps (A, C) overgrew the roots slightly stronger (about 14.5\%) that those collected from trees (B), but differences were not significant $(p>0.05)$. There were no differences between genotypes isolated from pines and beaches $(p>0.05)$, either (Table 3$)$. 
Table 2. Analysis of variance of wood discoloration length of Scots pine roots infected by different genotypes of $H$. annosum, $\alpha=0.05$

Tabela 2. Analiza wariancji długości przebarwienia drewna korzeni sosny zwyczajnej inokulowanych różnymi genotypami $H$. annosum, $\alpha=0,05$

\begin{tabular}{lccccc}
\hline & SS & $\begin{array}{c}\text { Degree } \\
\text { Stopień }\end{array}$ & MS & $F$ & $p$ \\
\hline Genotype - Genotyp & 5819.95 & 19 & 306.31 & 30.715 & 0.00 \\
Error - Błąd & 398.92 & 40 & 9.97 & & \\
\hline
\end{tabular}

Table 3. Homogenous groups on the base of HSD Tuckey test in terms of mycelium ability to overgrow the roots' wood

Tabela 3. Grupy homogeniczne pod względem zdolności przerastania drewna korzeni na podstawie testu HSD Tuckeya

\begin{tabular}{|c|c|c|c|c|c|c|c|c|c|}
\hline \multirow{2}{*}{$\begin{array}{l}\text { Genets } \\
\text { Genotypy }\end{array}$} & \multirow{2}{*}{$\begin{array}{l}\text { Mycelium range } \\
\text { Rozmiar grzybni } \\
\text { cm }\end{array}$} & \multicolumn{8}{|c|}{ Homogenous groups - Grupy homogeniczne } \\
\hline & & 1 & 2 & 3 & 4 & 5 & 6 & 7 & 8 \\
\hline $\begin{array}{l}\text { Control } \\
\text { Kontrola }\end{array}$ & 2.16 & $* * * *$ & & & & & & & \\
\hline $\mathrm{BCZ1}$ & 8.1 & $* * * *$ & & & & & & & \\
\hline $\mathrm{BCZ4}$ & 18.4 & & $* * * *$ & & & & & & \\
\hline $\mathrm{ACZ2}$ & 19.6 & & $* * * *$ & $* * * *$ & & & & & \\
\hline $\mathrm{BCZ2}$ & 20 & & $* * * *$ & $* * * *$ & $* * * *$ & & & & \\
\hline CCZ10 & 20.03 & & $* * * *$ & $* * * *$ & $* * * *$ & & & & \\
\hline $\mathrm{BCZ5}$ & 25.5 & & $* * * *$ & $* * * *$ & $* * * *$ & $* * * *$ & & & \\
\hline $\mathrm{CCZ4}$ & 25.6 & & $* * * *$ & $* * * *$ & $* * * *$ & $* * * *$ & & & \\
\hline $\mathrm{CCZ5}$ & 26.63 & & $* * * *$ & $* * * *$ & $* * * *$ & $* * * *$ & & & \\
\hline CCZ7 & 29.17 & & & $* * * *$ & $* * * *$ & $* * * *$ & $* * * *$ & & \\
\hline CCZ6 & 29.5 & & & & $* * * *$ & $* * * *$ & $* * * *$ & & \\
\hline ACZ3 & 30.47 & & & & & $* * * *$ & $* * * *$ & & \\
\hline CCZ9 & 31.2 & & & & & $* * * *$ & $* * * *$ & $* * * *$ & \\
\hline CCZ2 & 31.33 & & & & & $* * * *$ & $* * * *$ & $* * * *$ & \\
\hline CCZ8 & 32.17 & & & & & $* * * *$ & $* * * *$ & $* * * *$ & \\
\hline CCZ1 & 33.63 & & & & & $* * * *$ & $* * * *$ & $* * * *$ & $* * * *$ \\
\hline CCZ11 & 35.17 & & & & & $* * * *$ & $* * * *$ & $* * * *$ & $* * * *$ \\
\hline BCZ6 & 36.63 & & & & & & $* * * *$ & $* * * *$ & $* * * *$ \\
\hline ACZ1 & 40.47 & & & & & & & $* * * *$ & $* * * *$ \\
\hline BCZ3 & 43.27 & & & & & & & & $* * * *$ \\
\hline
\end{tabular}




\section{DISCUSSION}

Individual pathogen's genotype, that was tested in this study grew in the wood of stumps' root at different rate. After one year of inoculation the mycelium was isolated from $8.1 \mathrm{~cm}(\mathrm{BCZ1})$ to 43.27 (BCZ3) from inoculation point (average $28.26 \mathrm{~cm})$. Heterobasidion annosum genotypes belonged to 8 homogenous group in the rate of wood colonization. The only isolate BCZ1, that grew in the wood at the lowest rate, differed significantly from other isolates.

Results of this work are comparable to other infection experiments. Roll-Hansen and Roll Hansen (1981) showed that the Heterobasidion mycelium overgrew wood in roots on average from $20 \mathrm{~cm}$ to $38 \mathrm{~cm}$ after inoculation in Norway spruce roots and from 11 $\mathrm{cm}$ to $12 \mathrm{~cm}$ in Sitka spruce roots per year. In addition Pagony (1981) found that a year after stumps inoculation the mycelium colonized wood up to $40 \mathrm{~cm}$ from inoculation point in the environment favourable to pathogen.

The growth rate in stumps wood could be also higher than we obtained in this work. In infection experiments the growth rate depended on the climate or host species. Meredith (1960) found that mycelium grew $7.2 \mathrm{~cm}$ per month in Scots pine stumps, whereas Cobb and Barber (1968) in warmer climate of California showed the mycelium growth of $15-21 \mathrm{~cm}$ per month.

The ability of dead wood colonization plays a crucial role in a pathogen's secondary spread in stands through stumps its roots to roots and stem of live trees. Mańka et al. (1974) proved that infection and colonization intensity depended on width of wood ring increment. Stumps with wider wood rings were faster colonized than stumps with narrow wood rings. The ratio of summer wood to late wood is an important factor in rate of wood colonization by Heterobasidion mycelium.

Oliva et al. (2011) found that probability of pathogen's transfer from inoculated stumps to neighbour trees via roots contacts depended on stump diameter and suggested that this fact is related to size of late wood in annual rings. After fifteen years Norway spruce stumps inoculations by different genotypes of $H$. patrviporum mycelium spread on distance from $1.96 \mathrm{~m}$ to $4.23 \mathrm{~m}$. During this time $H$. parviporum genets infested appropriately 1.26 to 3.01 trees, while genotypes of $H$. annosum colonized distance 1.51 to 2.92 trees. In this experiment the pathogen was inserted on stumps surface by conidial spores.

Isolates, which mycelium overgrew the wood on distance more than $30 \mathrm{~cm}$ significantly differed $(p<0.05)$ of those that mycelium colonize the wood on distance shorter than $20 \mathrm{~cm}$. Genotypes, which mycelium had the highest growth rate in dead wood were the most aggressive to Scots pine seedlings (according to previous study Cieślak et al., 2011). On the other hand isolates that overgrew the smallest portion of wood displayed the average level of aggressiveness. Genets isolated from dead trees had a lower growth rate than those isolated from stumps but differences were not statistically significant. Similar results were obtained by Cieślak et al. (2011) in infection experiment with the same isolates on Scots pine seedlings. Isolates collected from stems of Scots pine had lower aggressiveness than those isolated from stumps. It seems that the ability of wood 
colonization by H. annosum mycelium, both in live and dead wood is rather an ontogenetic feature than it is connected with a colonized source in the forest environment.

Stumps after thinning and clear cuttings are the most important pathogen source in current and even next generation of forest. Greig and Pratt (1976) showed that Heterobasidion is able to survive in stumps for decades. They found active pathogen's mycelium in 33-62-year-old Scots pine stumps, 30-46-year old larch and 30-year-old Douglas fir stumps, Norway and Sitka spruce.

Not only colonized stumps could increase a disease risk in stands. Similarly to stumps and roots, lying logs or wood debris could be infected by Heterobasidion and become a disease source. Schütt and Schock (1979) emphasized that released dead wood (logs with Heterobasidon decay) in Norway spruce stand could increase infection risk. On wood debris Heterobasidion sporocarps producing a lot of basidiospores could appeared. Sporocarps appeared on 50\% of decayed stems. Nitisa et al. (2013) present similar results. They found that wood debris left in stand could influence a faster pathogen spread. They showed that sproocarps appeared on windthrown Norway spruces were more frequent and bigger in comparison with those created on roots. In turn sporocarps produced on excavated stumps were bigger from those on standing stumps. The most frequent sporocarps occurred in stands on wet sites growing on drained peat soil.

In addition Pratt and Greig (2013) found that Heterobasidion could survive in saprotrophic stage colonizing small wood debris of Scots pine roots about $2 \mathrm{~cm}$ in diameter even for 13 years. The longevity of active mycelium in stumps varied from 25 years in Scots pine stumps (Rishbeth, 1951) to even 46 years for Picea abies (Geig and Pratt, 1976; Laine, 1976; Piri, 1996). So even the less extensive in growth rate genotypes through years of stumps existence after thinning could create a dangerous source in the wood of stumps and its roots for the neighbour trees infection.

That is why the stumps excavation seems to be a very important treatment to decrease the risk of Heterobasidion infection and amount of pathogen source in stumps. After this treatment the possibility of pathogen spread is smaller both in generative and vegetative way (Greig, 1984; Piri, 2013; Arhipova et al., 2013).

In conclusion population of $H$. annosum differed in genotypes features conditioning the rate of its development in the environment and disease dynamics. Differentiation of these features of pathogen populations caused an unequal infection and disease development rate in stands. Genets with high pathogenic potential have also a high level of saprotrophic features. It seems that the most aggressive isolates colonize the stand fastest through root system.

\section{REFERENCES}

Arhipova, N., Thomsen, I. M., Stenlid, J., Vasaitis, R. (2013). Stumps removal trials to control root-rot in Picea abies stands in Scandinavia. In: P. Capretti, C. Comparini, M. Garbelotto, N. La Porta, Santini A. (Eds.), Proceedings of the XIII International Conference on Root and 
Butt Rot of Forest Trees. Firenze (FI) - S. Martino di Castrozza (TN), Italy 4th-10th September 2012. Firenze: Firenze University Press.

Bobrowski, D. (1980). Probabilistyka w zastosowaniach technicznych [Probabilistic in technical perspective]. Warszawa: WNT [in Polish].

Cieślak, R., Łakomy, P., Molińska-Glura, M. (2011). Description of Heterobasidion annosum sensu stricto population occuring in Scots pine stands in Człopa and Podanin Forest Districts. I. Mycelium development in alive wood. Acta Sci. Pol. Silv. Colendar. Rat. Ind. Lignar., 10(3), 15-25.

Cobb, F. W., Barber, H. W. (1968). Susceptibility of freshly cut stumps of redwood, Douglas fir, and ponderosa pine to Fomes annosus. Phytopathology, 58, 1551-1557.

Dalke, M., Łakomy, P. (2009). Genetic diversity of Heterobasidion annosum sensu stricto populations in chosen Scots pine stands with beech in understorey. Acta Sci. Pol. Silv. Colendar. Rat. Ind. Lignar., 8(2), 17-24.

Greig, B. J. W. (1984). Management of East England pine plantations affected by Heterobasidion annosum root rot. Eur. J. For. Pathol., 14, 392-397.

Greig, B. J. W., Pratt, J. E. (1976). Some observations on the longevity of Fomes annosus in conifer stumps. Eur. J. For. Pathol., 6, 250-253.

Kala, R. (2002). Statystyka dla przyrodników [Statistics for naturalists]. Poznań: Wyd. AR [in Polish].

Karlsson, J.-O. (1994). Genetic variation in Heterobasidion annosum detected with M13 fingerprinting and ribosomal DNA probes. Exp. Mycol., 18, 48-56.

Korhonen, K. (1978). Intersterility groups of Heterobasidion annosum. Commun. Inst. For. Fenniae, 94(6).

Korhonen, K., Capretti, P., Karjalainen, R., Stenlid, J. (1998). Distribution Heterobasidion annosum intersterility groups in Europe. In S. Woodward, J. Stenlid, R. Karjalainen, A. Hütermann (Eds.), Heterobasidion annosum. Biology, ecology, impact and control (pp. 93-104). Cambridge: University Press.

Laine, L. (1976). The occurance of Heterobasidion annosum (Fr.) Bref. in woody plants in Finland. Commun. Inst. For. Fenniae, 90(3), 1-53.

Łakomy, P., Broda, Z., Werner, A. (2007). Genetic diversity of Heterobasidion spp. in Scots pine, Norway spruce and European silver fir stands. Acta Mycol., 42(2), 203-210.

Mańka, K. (2005). Fitopatologia leśna [Forest pathology]. Warszawa: PWRiL [in Polish].

Mańka, K., Dyspolska, W., Mańka, M., Szurkowski, L. (1974). Wpływ szerokości słojów drewna pniakowego i siedliska leśnego na porażenie pniaków sosny zwyczajnej przez grzyb Fomes annosus (Fr.) Cke [Effect of wood density of pine stumps and forest site on infection of pine by Fomes annosus (Fr.)]. Rocz. Nauk Roln. AR Pozn., 4, 97-107 [in Polish].

Meredith, D. S. (1960). Further observations on fungi inhabiting pine stumps. Ann. Bot. 24, 63-78.

Nitisa, D., Gaitnieks, T., Stivrina, B., Donis, J., Korhonen, K., Vasaitis, R. (2013). Dynamics of Heterobasidion sporocarp formation on coarse woody debris retained on harvested Picea abies sites. In: P. Capretti, C. Comparini, M. Garbelotto, N. La Porta, A. Santini (Eds.), Proceedings of the XIII International Conference on Root and Butt Rot of Forest Trees. Firenze (FI) - S. Martino di Castrozza (TN), Italy 4th-10th September 2012 (pp. 107-108). Firenze: University Press.

Oliva, J., Bendz-Hellgren, M., Stenlid, J. (2011). Spread of Heterobasidion annosusm s. s. and Heterobasidion parviporum in Picea abies 15 years after stump inoculations. FEMS Microbiol. Ecol., 75, 414-429.

Pagony, H. (1981). Ecological conditions of Fomes annosus (Fr.) Cooke infection in Hungarian pine stands. In: Root and Butt Rots in Scots pine stands. European Regional Meeting, IUFRO 
Working Party S2.06.01 (pp. 29-33). Poznań, Poland. Polish Academy of Sciences. Committee of Forest Sciences.

Piri, T. (1996). The spreading of the $\mathrm{S}$ type of Heterobasidion annosum from Norway spruce stumps to the subsequent tree stand. Eur. J. For. Path., 26, 193-204.

Piri, T. (2013). Inoculum of Heterobasidon parviporum on stump-harvested sites. In: P. Capretti, C. Comparini, M. Garbelotto, N. La Porta, A. Santini (Eds.), Proceedings of the XIII International Conference on Root and Butt Rot of Forest Trees. Firenze (FI) - S. Martino di Castrozza (TN), Italy 4th-10th September 2012 (pp. 219-220). Firenze: University Press.

Pratt, J. E., Greig, B. J. W. (2013). Survival of Heterobasidion annosum in buried pine roots. In: P. Capretti, C. Comparini, M. Garbelotto, N. La Porta, A. Santini (Eds.), Proceedings of the XIII International Conference on Root and Butt Rot of Forest Trees. Firenze (FI) - S. Martino di Castrozza (TN), Italy 4th-10th September 2012 (pp. 98-101). Firenze: University Press.

Redfern, D. B., Stenlid, J. (1998). Spore dispersal and inoculation. In: S. Woodward, J. Stenlid, R. Karjalainen, A. Hütermann (Eds.), Heterobasidion annosum. Biology, ecology, impact and control (pp. 105-124). Cambridge: University Press.

Rishbeth, J. (1951). Observations on the biology of Fomes annosus with particular reference to East Anglian pine plantations. (II) Spore production, stump infection, and saprophytic activity in stumps. Ann. Bot. NS, 15(57), 1-21.

Roll-Hansen F. Roll-Hansen H., 1981. Root wound infection of Picea abies at three localities in southern Norway. Meddelelser fra Norsk Institutt for Skogforskning, 36(4), 1-18.

Stenlid, J. (1985). Population structure of Heterobasidion annosum as determined by somatic incompatibility, sexual incompatibility and isoenzyme patterns. Can. J. Bot., 63, 2268-2273.

Stenlid, J., Swedjemark, G. (1988). Differntial growth of S- and P-isolates of Heterobasidion annosum in Picea abies and Pinus sylvestris. Trans. Br. Mycol. Soc., 90(2), 209-213.

Stenlid, J., Redfern, D. B. (1998). Spread within tree to stand. In: S. Woodward, J. Stenlid, R. Karjalainen, A. Hütermann (Eds.), Heterobasidion annosum. Biology, ecology, impact and control (pp. 125-142). Cambridge: University Press.

Schütt, P., Schuck, H. J. (1979). Fomes annosus sporocarps - their abundance on decayed logs left in the forest. Eur. J. For. Path., 9, 57-61.

Werner, A., Łakomy, P. (2002). Host specialization of IS-group isolates of Heterobasidion annosum to Scots pine, Norway spruce and common fir in field inoculation experiments. Dendrobiology, 47, 59-68.

\title{
CHARAKTERYSTYKA POPULACJI HETEROBASIDION ANNOSUM WYSTĘPUJĄCYCH W DRZEWOSTANACH SOSNOWYCH NADLEŚNICTWA CZLOPA II. ROZWÓJ GRZYBNI W MARTWYM DREWNIE
}

\begin{abstract}
Streszczenie. Do badań wybrano populacje patogena o znanej agresywności w stosunku do sadzonek sosnowych (Cieślak i in., 2011). W doświadczeniu wykorzystano 19 izolatów reprezentujących różne genotypy $H$. annosum pochodzące $\mathrm{z}$ dwóch 45 -letnich drzewostanów sosnowych oraz z 12-letnich sosen i buków rosnących w gniazdach zlokalizowanych w drzewostanie 33-letnim. Wszystkie drzewostany w Nadleśnictwie Człopa rosły na gruntach porolnych. Identyfikację grzybów przeprowadzono dzięki testom genetycznej zgodności grzybni, a rozróżnienie genotypów - testami somatycznej kompatybilności.
\end{abstract}


Podobieństwo genetyczne populacji patogena określono we wcześniejszych badaniach za pomocą reakcji PCR (Cieślak i in., 2011). Inokulum były kołki drewniane o długości $5 \mathrm{~cm}$ i średnicy $1 \mathrm{~cm}$ przerośnięte przez grzybnię patogena. Inokulum wprowadzano w dziury wywiercone wiertłem w korzeniach pniaków w odległości $50 \mathrm{~cm}$ od karpy. Miejsce wprowadzenia zaklejano sztuczną korą, a korzenie przykrywano glebą. Kontrolę tworzyły korzenie inokulowane sterylnymi kołkami drewna. Po 12 miesiącach korzenie odkopywano i pozyskiwano, odcinając w odległości $50 \mathrm{~cm}$ w każdą stronę od miejsca inokulacji. Po rozłupaniu korzeni analizowano długość strefy przebarwienia spowodowaną przez rozwijającą się grzybnię $H$. annosusm. Dodatkowo wykonano izolację z miejsc przebarwionych dla potwierdzenia obecności grzybni patogena. Grzybnia zasiedliła drewno i spowodowała jego przebarwienie od 8,10 cm (genotyp BCZ1) do 43,27 cm (izolat BCZ3). Drewno korzeni zostało przerośnięte najsilniej przez izolaty pochodzące z powierzchni A: o $17 \%$ silniej niż z powierzchni B i 3\% z powierzchni C. Analiza zdolności przerastania drewna korzeni pniakowych przez genotypy patogena w zależności od pochodzenia wykazała, że genotypy pochodzące z pniaków przerastały drewno korzeni nieco silniej niż pochodzące $\mathrm{z}$ drzew, ale różnica nie była statystycznie istotna $(p>0,05)$. Nie było także różnic pomiędzy genotypami pozyskanymi z sosen i buków. Izolaty wykazujące największe tempo wzrostu w martwym drewnie charakteryzowały się we wcześniejszych badaniach najsilniejszą agresywnością. W populacji patogena występuje zróżnicowanie cech poszczególnych genotypów warunkujące tempo ich rozprzestrzeniania w środowisku oraz dynamikę procesu chorobowego. Zróżnicowanie tych cech w populacji patogena wpływa na nierównomierność porażenia i tempo rozwoju choroby w poszczególnych drzewostanach. Genotypy o wysokim potencjale patogeniczności wykazują także wysoki poziom właściwości saprotroficznych. Wydaje się, że najbardziej agresywne genotypy patogena wykazują największe tempo kolonizacji drzewostanu.

Słowa kluczowe: Heterobasidion annosum, genotypy, sosna zwyczajna, wzrost saprotroficzny

Accepted for print - Zaakceptowano do druku: 22.10.2015

For citation - Do cytowania: Cieślak, R., Behnke-Borowczyk, J., Raźny, T., Molińska-Glura, M., Ratajczak, A., Świetlik, A., Łakomy, P. (2015). Description of Heterobasidion annosum population occurring in Scots pine stands in Człopa Forest Districts. II. Mycelium development in a dead wood. Acta Sci. Pol. Silv. Colendar. Rat. Ind. Lignar., 14(2), 93-102. DOI: 10.17306/J.AFW. 2015.2.9 